\title{
Young Europeans' constructions of a Europe of human rights
}

Alistair Ross 1

\section{How to cite this article}

Ross, A. (2020) 'Young Europeans' constructions of a Europe of human rights'. London Review of Education, 18 (1): 81-95. https://doi.org/10.18546/LRE.18.1.06

Submission date: 16 February 2019

Acceptance date: 1 October 2019

Publication date: 1 March 2020

\section{Peer review}

This article has been peer reviewed through the journal's standard double-blind peer review, where both the reviewers and authors are anonymized during review.

\section{Copyright}

(C) Copyright 2020 Ross. This is an Open Access article distributed under the terms of the Creative Commons Attribution Licence (CC BY) 4.0 https://creativecommons.org/licenses/by/4.0/, which permits unrestricted use, distribution and reproduction in any medium, provided the original author and source are credited.

\section{Open access}

London Review of Education is a peer-reviewed open-access journal. 


\title{
Young Europeans' constructions of a Europe of human rights
}

\author{
Alistair Ross* - London Metropolitan University, UK
}

\begin{abstract}
This article argues that many young people (11 to 19) in Europe articulate a construction of their identity that includes a European element. This articulation is often initially made in instrumental terms, but through deliberative discussion can move to become more idealistic. The data is drawn from over 300 small discussion groups across 29 European countries, and it suggests that the 'specific risks' to European values described by the Council of Europe in 2011 are not held by the younger generation. Contemporary and local political events were used in discussion to construct ideas of Europe as representing, for them, a relatively unique phenomenon of a group of countries who they felt shared similar conceptions of human rights, and who sought to enforce them. These included the acceptance of diversity (in terms of sexuality, gender and ethnicity), of freedom of expression within particular limits, of the obligations of countries to organize social services, and of participation in democratic processes. Discussion groups were held over the 2010 to 2016 period. The methodology adopted was particularly non-directive, and each discussion moved according to the interests of the group, so no quantitative analysis of this phenomenon is possible; but the overall impression is of a generation of young people who largely express support for rights-based societies, and reject intolerance, nationalism and authoritarian behaviours. The methodology used may have potential pedagogic implications.
\end{abstract}

Keywords: human rights, Europe, young people, identities

\section{Introduction and context}

This article presents some findings of a personal post-retirement research project that I began in 2010 (Ross, 2015, 2019). Its purpose was to examine the ways in which young people in mainland Europe, between the ages of 11 and 19, constructed identities for themselves that might include such entities as their country and Europe. I visited over 104 different towns, cities and villages (with populations between five hundred and 13 million) in 29 European countries, and in each engaged in discussions with small groups of 11-19-year-olds, talking with some 2,000 of them in 324 conversations. I was working with the understanding that most people will not necessarily have firm and fixed senses of identity: the ways in which a person chooses to describe their identities will depend on the context in which they are engaged (Bauman, 2000; Bruter, 2005; Balescu, 2009; Anthias, 2012).

The concept of European citizenship was initiated soon after the publication of the constructivist analyses of Anderson (1992) and Gellner (1983). The status and implicit identity of European citizenship was introduced by the European Union's (EU) Maastricht Treaty in 1992: 'Citizenship of the Union is hereby established. Every person 
holding the nationality of a member state shall be a citizen of the Union' (CEC, 1992: Article 8.1). But there was little examination of what this might mean, either in the eyes of the Commission or the minds of these Europeans.

There is some quantitative data suggesting that younger people generally were more positive about including a European element in their identity. The Eurobarometer opinion survey, conducted every six months for the European Commission in every state in the Union (and candidate states) since the mid-1970s has shown that more younger people describe themselves as either 'European' or as 'European and their own country' than describe themselves as 'their country and European' or as only of 'their country'. This has been analysed by Lutz et al. (2006) to suggest that cohorts of people born more recently are less likely to adopt a solely national identity, and are more likely to express multiple (including European) identities. They concluded that there was 'a strong and highly significant positive cohort effect', which represented 'long-term tectonic shifts in identity that are likely to have major and enduring consequence' (ibid.: 425).

The idea of a cohort effect is important: this means that the cohort will continue to act this way as they age (rather than change, as an effect of ageing). Fulbrook (2011: 11) has used historical qualitative data to suggest that in the twentieth century, German young people formed a series of cohorts, each of which formed 'a collective identity on the basis of generationally defined common experiences'. Identities were constructed by each generation as the consequence of political fractures and dissonance in national society, and the age at which people experience key historical moments, such as the transitions within German society in 1933, 1945 and 1989, were a critical explanatory factor behind an individual or group's 'availability for mobilisation' for political expression (ibid.: 488).

What these young Europeans talked about in the discussion groups, often extensively, were human rights issues, particularly with respect to the idea of European distinctiveness, and the analysis of this will be the main thrust of this article. This is also set in the context of the identification of 'eight specific risks' to Council of Europe (CoE, 2011) values identified by a working party led by Joskcha Fischer in 2011, established in response to concerns by European governments to real and perceived threats to social cohesion across Europe. The working party suggested that the following were threats to the principles of the European Convention on Human Rights, especially to individual freedom and equality before the law:

- rising intolerance

- rising support for xenophobic and populist parties

- discrimination

- the presence of a population virtually without rights

- parallel societies

- Islamic extremism

- loss of democratic freedoms

- a possible clash between religious freedom and freedom of expression.

Behind these, they suggested, were 'insecurity (stemming from Europe's economic difficulties and sense of relative decline); the phenomenon of large-scale immigration (both as actually experienced and as perceived); distorted images and harmful stereotypes of minorities in the media and public opinion; and a shortage of leaders who can inspire confidence' (ibid.: 5). The data collected in this survey suggest that, for many young people these are equally issues of concern, but that they are attitudes that most of them reject, and that many perceive as being primarily held by older people. 
In order to explore what values young Europeans held, and what they thought that 'being European' means, a qualitative methodology seemed to be the most promising approach.

\section{Methodology}

Constructions of identities and the expression of values are social activities: they take place in social settings, and are contingent on the particular circumstances in which they are expressed. But young people of school age may be a particularly difficult group to ask questions of, not least because they are accustomed to much adult questioning being directed at testing their knowledge. Most questions put to young people in schools are closed: the questioner knows the answer, and the task of the young person is (if they are compliant) to demonstrate that they can provide a correct response.

My approach was therefore to initiate small group deliberative discussions, where between five and eight young people would feel that they controlled the subject, and could discuss issues with each other using their own vocabulary, rather than in response to my agenda and terminology. Group members would manage pace and direction. Open-ended questions, often made in response to what had been said, elicited their sense of attachment to their locality, country and other locations that might represent political identities. The apparent lack of structure was designed to capture and use the narratives of the young people themselves - for example, I would initially refer to 'your country', letting them (perhaps) introduce terms such as 'state' and 'nation', and only then enquire about what they meant by their terms, and for examples and contexts.

Group conversations (gruppendiskussionsverfahren: group discussion method) have been developed in German social science research since the 2000s (Bohnsack, 2000; Loos and Schäffer, 2001). Described as 'an open interview, intended to let respondents develop a topic in their own language, in their symbolic system and their relevant framework', the technique allows analysis that 'avoid[s] projecting into single utterances meanings that are not appropriate' (Bohnsack, 2000: 21, translated by Scheunpflug et al., 2016). Gugglberger et al. (2015) suggest this as 'a very open and flexible method of data generation ... in comparison to the more structured focus group' (2015: 127). It is a process 'in which respondents can set the structures and contents of the conversation by themselves' (Scheunpflug et al., 2016: 10), producing 'conjunctive knowledge ... implicit, action-guiding knowledge ... based and acquired in fundamental experiences ... that groups of individuals share with each other' (Wagener, 2018: 92). My method was to provide narrative-generating stimuli to initiate discussion, beginning with immanent issues - the topics, accounts and language that the group members use in their narratives - and only later moving to ask exmanent questions - my own agenda of themes - when they had had the opportunity to develop structures they found relevant.

Groups were assured that there were no 'right' answers, and that they should say if they disagreed with each other. This was to establish an empowering rapport, in which discussion was substantially directed and paced by group members. My strategies to generate such a dialogue were:

- not to introduce leading terminology

- to make questions transparently open (if they said they were French, I might respond 'What makes you French?')

- to accept all responses as valid

- where possible, to construct questions that responded to what had been said 
- to ask as few questions as possible

- not to expect everyone to respond (not a sequential interview)

- to ask for examples.

Most young people (about 95 per cent) made more than a minimal contribution: two thirds could be described as fully participant for the entire session. The conversations were varied in focus and emphasis, and my questions changed in response, and in their wording, in order to maintain a conversational rather than an interrogatory mode. While I had areas that I wanted to explore, the interactive nature of the discussion made responses difficult to quantify. The majority of discussions were in English; the others were simultaneously translated by my local colleague.

I used my networks and contacts in European universities to assemble small groups of young people in 104 locations. Each of my contacts who was able to cooperate was asked to identify two schools or colleges in their locality who would cooperate, one from a working-class district, one from a middle-class district. Generally, two groups, from classes of different ages, were recruited, asking for about six to eight young people, half of which should be female, who were willing to participate and discuss issues. They were asked not for the most or least able students, and to select from the population of the school, not just formal citizens, including where possible an appropriate representation of any minorities.

My first phase of fieldwork (2010-12) covered the countries that had joined the EU after 2004; a second phase (2014-16) added many of the pre-2004 members. At least two places were visited in each country, and four or more in the larger countries (Greece and the UK were not included). The young people participating were diverse: some 56 per cent were female, and about half had parents in working-class occupations. There were minority-origin young people in many discussion groups, reflecting the distribution of minorities in each country and Europe as a whole: by country of origin, 77 per cent had parents and grandparents from the country they were living in: of the remainder, 7.4 per cent had at least one parent/grandparent from another EU country, 8.4 per cent from a European country not in the EU, and 7.4 per cent from outside Europe (figures based on what was volunteered in discussion). This was not intended to be a statistically representative sample, but a range of potential views across each country - from different regions, social backgrounds and cultural origins.

Ethical approval was given by the Faculty Research Ethics Committee of my former institution (London Metropolitan University) in 2009 and 2014, and was (for the first phase) based on the British Educational Research Association's Revised Ethical Guidelines for Educational Research (BERA, 2004) or (for the second phase) on the subsequent set of guidelines (BERA, 2011). Consent was obtained from school principals, and written consent from the young people's parents (for all of those under 16 , and older in some countries) and from the young people themselves. Letters to parents, in the national language, explained that I was 'making a small study of young people's ideas ... about how they feel as part of their community, region and country', gave details of my local colleague for further information, and specified that they could withdraw from the study at any stage. All names used here are pseudonyms.

Much empirical social science research draws subjects from a narrow base: Arnett (2008) estimates that 80 per cent of non-USA studies are drawn from psychology undergraduates in the capital city of a country. These are extrapolated as representative of the country (Rozin, 2001). Within the constraints that the population being sampled was of young residents of these European countries (largely industrialized, democratic and comparatively rich), the recruitment process was designed to avoid the pitfalls analysed by Henrich et al. (2010). Further, the study was designed to uncover the 
range and diversity of opinion, rather than to arrive at a generalized summary of young people's opinions. Bourdieu was critical of the assumption that opinions and beliefs could be statistically summarized. He argued that 'public opinion is an artifact, pure and simple, whose function is to conceal that the state of opinion at a given moment of time is a system of forces and tensions. There is nothing more inadequate to represent the state of opinion than a percentage' (Bourdieu, 1973: 1295, emphasis as in original). He observed that not everyone has an opinion on every issue, that the simple summation of what opinions are expressed only produces 'meaningless artifacts' (ibid.: 1292), and that using an identical question with all respondents implies that there must be a consensus about the validity of the issue that is being addressed. Rochat (2010: 107) points out that 'in academia, a priori claims of universality sell better than diversity, which complicates rather than simplifies matters ... This tends to relegate diversity to noise rather than as a primary object of study'. This study was intentionally noisy, reflecting the diverse populations of these countries, and exploring the particular issues of concern that the participants raised about their political identities, in the vocabulary and terms that they raised them.

\section{Findings: A Europe of human rights}

Each discussion began with members describing what they had in common: often this might be that they were French (or Algerian, or Moroccan, for example). I would then ask why they were French (or Algerian, or Moroccan ...), which led to talk of birthplace, parents' and grandparents' identities, language, upbringing, culture and more. Identities were often described as mixed, and were held for multiple reasons. For most, their 'nationality' was seen as accidental. In Sevilla, Sancho (M 14) described his citizenship as 'a lottery', while in Prilep, Lazar (M 18) said they were 'Macedonians, but not by choice - we are unlucky to be born here'. Alida (F 16) felt lucky to born in the Netherlands: 'If I was born in Syria, I would be running away from that.' Being born as citizens of a particular state is today like a feudal inheritance that preserves wealth and privilege (Shachar, 2009). For only a few young people was their country identity essentialized; Janko (M 15), living in Slagelse (Denmark), said: 'I'm Serbian ... if I marry a Serbian girl, [my children] will be Serbian.'

A significant minority, particularly in the Nordic countries, were antipathetic to the concept of nationality. In Stockholm, Saga (F 16) said, 'Swedish is nothing more than my passport says that I'm Swedish,' and Margreta (F 16) added she was concerned about being seen as 'Swedish': 'there's this nationalistic movement ... I don't want to be whatsoever identified with ... it's become important to not identify myself with where I live, or where people are from.'

Were there aspects of this country-identity that they were pleased about? (Often not a great deal.) Were there things about the country they were less proud of, that they would like to change? This usually provoked a longer and more voluble discussion. Many points made were contingent on the particular location and specific moment. In countries that had joined the EU post-2004 they raised issues of corruption, or in the Baltic states uncertainties about Russian intentions in the wake of the incursions in Georgia and Ukraine; in Western states there were concerns about racism, xenophobia and the position of refugees (particularly in discussions in the later half of 2015 and early 2016). For example, in the Croatian town of Zadar a group talked of the recent television appearance of the former Prime Minister (and local politician), Ivo Sanader, who was the subject of corruption changes; and in Malmö they discussed the behaviour of the local right-wing Swedish Democrat candidate in the elections a month earlier. 
I then moved the conversations on, to talk about if they thought their views were also held by other people in the country - of different generations, of different provinces. Older people, particularly in newer EU states, were often seen as bound by what the young people saw as old-fashioned ways of thinking. For example, in Warszawa (Poland) a group suggested that older people were nationalist and Catholic, because this had been a form of resistance to Soviet hegemony in the period between 1945 and 1989: now these young people, all born after this, saw it as no longer relevant. Sergiusz (M 16) said that then 'it was something important - religion mattered. Now, religion doesn't matter so much in the younger generation'. He attributed this to both cosmopolitan influences and to the 'problems of concern to this generation, such as homophobia and euthanasia'.

In the Western counties, older people were often described as racist. In København, Alvilda (F 18) complained about her parents' racist jokes: 'I don't think they realize that they are being racist ... it's just the way that [they were] brought up.' In Roubaix (France), Colette (F 18, Congolese born) blamed racist attitudes on family 'indoctrination ... from when you are born, your family keeps repeating that black people are not good'. There were also expressions of racism by a minority of young people.

Many saw themselves as having agency in changing matters. In Frascati (Italy), Lamberto (M 16) argued: 'we can change the world, because government is what we are - if we change on stupid things like racism or corruption ... It isn't just a problem of government, it is our problem.' In Wien (Austria), some young people had voted the day before the discussion (some for the first time; the franchise is open to 16-yearolds). Cordula (F 16) argued that while voting was significant, 'you can make much more change than through voting if you go on the street and demonstrate. I do this - the next one's on Friday, and it's the right-wing party's ball in Vienna, the Akademikerball I'll be there!' This was a reference to an annual pan-European gathering of right-wing parties and organizations.

Their country identity, as expressed in these discussions, was usually constructed with some affection and understanding, but in the great majority of cases as nonnationalistic (compare Anderson, 1992). After talking about this for perhaps 25 to 30 minutes, I intervened to shift the focus of the discussion: as well as these feelings of attachment (or not) to a country, did they also, sometimes, feel that they were European in any way?

The conversations that followed were often initially unfocused and disconnected. There were uncertainties about whether there was a shared European culture. Some at first denied that European society had any defining characteristics. Initially they often talked about differences between the food, cultures and histories of other countries. But often, as the discussions progressed, a spectrum of constructs of the meaning of Europe emerged, and very often there was a particular spectrum of constructs, which emerged in a particular sequence.

A few regarded the term 'European' as a simply ascribed characteristic: they lived in a land mass called Europe, ergo they were European; their country was located in Europe, they were therefore a European. In Sevilla, Salvador (M 15) said, 'you feel Spanish because you are born in Andalucía; Spain belongs to Europe, so - if you are from Spain, you feel European.'

Instrumental reasons were often the first reasons suggested: the freedom to travel, study and work were often cited, particularly in the post-2004 member states: Afina in Oradea (F 15) wanted 'to go to study somewhere other than Romania - in Austria, for example'. The experience of travel seemed to confirm this sense of knowing 
other Europeans. In Warszawa, Bartosz (M 12), having travelled a little, found he now 'could go to Germany, move around, feel connected. I can go everywhere in Europe and know what to do there'. This instrumentalism was not only at the personal level: European support for disaster relief was mentioned, and the enhanced prospects that member states had for economic growth. In Skopje, Vasil (M 16) said EU membership would improve growth in Macedonia, and Petrunka (F 14) felt with joining 'the standard will rise ... if we are in the Union more and more will start - we will be much richer'.

Membership of European institutions also brought a sense of security. In Faro, Andréia ( $F$ 17) saw her European identity as a form of security for a small country; she said, 'our identity cards say we are from Europe ... I am a Portuguese citizen, but I am also a European citizen - that's important - it makes us feel [that] we matter in the world.' Feeling part of a larger community was comforting, both to those in relatively small countries such as the Netherlands, where Aat (M 16) said: 'I think I'm European - the time of small little countries running their own [things] is a bit over - Europe is one big country that works together,' and also to those in much larger states such as Germany, where Hans (M 18) said: 'Europe is the future of this continent to living in peace, without war.'

There were also some very specific mentions of a sense of European solidarity in late January 2015. Sylviane (F 16), in Frascati: 'I have to say I really felt European after what happened in Charlie Hebdo, because of the union that this created among Europeans'; and in another Italian group, Karine (F 16) said, 'at this particular moment, I feel very European, after what happened in France'. Europe was a place that was safe: later, in 2015, Tatiana (F 14) in Faro spoke of 'feeling European, it's kind of feeling safe in our place, like in our home'.

This instrumental view of Europe very often shifted as the discussion progressed. For example, in Luxembourg, Amaury (M 17) began by saying 'the greatest good that the European Union gave us is free circulation - this suppression of the borders is a gift'. But a few minutes later, he reflected further: 'It's also a thing of values, because in the European Union we should share all the same values - democracy, and liberty, liberty of expression, and that's also what the European Union stands for.' And still later: 'I think the main right is democracy - we see in Poland the big reaction by the European community, because there liberty of expression was partly suppressed. We have this sense of democracy in common, because of this reaction.' His reference was to the recent EU review of the Polish Government's possible violation of the standards of rule of law (Pop, 2016). Amaury's view of the EU's significance shifted over 15 minutes, from enabling passport-less travel to a power that could exercise sanctions against antidemocratic tendencies in a member state.

Another example came in the small Swiss town of Hombrechtikon: Danilo (M 14) began by describing Europe as 'different countries that agree on certain issues, in commerce and business'. His colleague, Bianka (F 12), then talked about Russia, and Danilo described Russians as 'not free to say what they want, and Europe there's freedom of opinion ... every country that wants to join should comply with the rules and laws of the European Union'. Why had he had moved from economic aspects to human rights? 'Now that I think about it, human rights are more important.'

A further example was Loes ( $F$ 17) in Brussels, who talked herself into being European. She began: 'I don't feel European - I guess that we have advantages in that it is easier to travel, I like that ... so it is easier.' A few minutes later: 'I think that Europe has this common goal ... to make Europe a better place, where everyone has equal rights. I don't think that we are there yet.' Then a colleague suggested that Putin was not very democratic. Loes exploded: 'not very democratic? I think Putin is not 
democratic at all - the complete opposite of what we want to do with the European Union - that would be the end, all people who are not straight will be prosecuted ... it would tear the European Union apart.'

In the newer member states, such as those in the Balkan states, there were similar shifts. Most still felt that they were not really European. Their liminal status was partly a matter of geography (in many discussions, Europe was to the west, and the Balkans - 'non-Europe' - to the east), and partly a matter of time ('we are not yet European'). For example, in lași in north-eastern Romania, Cristian (M 16) began by conceding that he was only European 'technically, on paper. We can't compare ourselves with European countries like Germany, England ... we aren't in the same bracket'. Later, he elaborated: it was a matter of money, but also of being efficient and of living conditions. A colleague said, 'In Romania, no one helps you - in Germany, if someone has a problem, the state helps.' Cristian then discussed Russia's relationship with Europe: Russia had a 'habit of exploiting other countries ... we Europeans don't do this anymore'. The group all agreed: I asked about the expression 'we Europeans'. The explicit shift was explained: 'we incline to be more Europeanish than Russian; we evolved towards the European'.

Europe often became defined by its stand on human rights. In Bernalda, a small town in the south of Italy, Maïté (M 19) proclaimed, 'I'm a European citizen because I have the same political rights as the others - that's important, people are equal before the law.' In İstanbul, two young Kurdish men were sure that their rights would be respected if they lived in the EU: Furkan (M 17) said, 'when you say "Europe", it reminds me first of human rights, and of great possibilities for freedom.'

It was not only that human rights had been established in Europe, but that the EU was active in ensuring that they were upheld. In Lille, a long discussion on rights was peppered with references to recent examples and violations. Pascaline (F 15) suggested that Turkey could not join the EU till they recognized the Ottoman role in the Armenian genocide. Laurence (M 16) raised the attempt by the Hungarian prime minister to reintroduce the death penalty in Hungary, and how the European Commission had frustrated this: 'that's a nice aspect of Europe, that he had to abandon it because ... he would have been sanctioned by Europe.' Blaise (M 15) recalled earlier EU diplomatic sanctions against the Austrian politician Jörg Haider: 'he took away some rights of homosexuals ... but the EU was there to restrain him - it's like a dog leash.'

It was the process of discussion itself that appeared to lead to this transformation towards collectively defining Europe as having a distinctive, sometimes unique, and valued political culture that focused on social and political rights. The context of this turn was often contingent on comparisons made with authoritarian regimes and with neo-liberal states such as the USA. These othering processes, which led to a more tautly defined sense of positively 'being European', centred on the recognition of a distinctive and shared approach to human rights.

\section{Findings: Young Europeans and the threats to the European Convention on Human Rights}

It will be clear from the foregoing that the risks to European values that were raised by the Council of Europe (CoE, 2011) were also seen as significant issues by a substantial number of young people, across most of Europe. They were seen not only as dangerous trends but also as ones that they tended to associate primarily with some members of a different and older generation and, less often, with some of the population living in more rural areas or smaller settlements. They also tended to be able to marshal 
arguments of resistance to these threats, and so to see that there was an imperative to do this.

The key argument in the CoE (2011: 5) report was that:

... identities are a voluntary matter for the individual concerned, and that no one should be forced to choose or accept one primary identity to the exclusion of others. ... European societies need to embrace diversity, and accept that one can be a 'hyphenated European' ... But this can work only if all long-term residents are accepted as citizens and if all, whatever their faith, culture or ethnicity, are treated equally by the law, the authorities and their fellow citizens. Like all other citizens in a democracy they should have a say in making the law, but neither religion nor culture can be accepted as an excuse for breaking it.

Young people's responses to each of the 'eight threats' are analysed in the following paragraphs.

There were many instances where the existence of intolerance was recognized. Generally - but by no means universally - young people in the groups wanted to counter intolerance. Sometimes this was rather unsophisticated. For example in Helsinki, when Kaia (16), a locally born young woman of Somali parentage, said she encountered a lot of prejudice, Vilhelm (M 18) was unsure: 'People say that there is so much racism - I have been expecting to see this ... so that I could fight back ... but I don't see it.' Aune (F 16) gently reproved him: 'If you are part of a minority you will see it better. If you are white and Finnish, no one will talk to you like that.' When Kaia detailed the abuse (from 'usually women, especially older ones, not young people'), Vilhelm was visibly shocked.

The negative response of some countries and individuals to the 2015 refugee 'crisis' provoked specific references to fundamental European values. In Madrid, Jaime (M 11) said 'now I feel less European ... all the continent should work as a group'. In Paris, Albane (F 17) said that European identity was threatened 'when some counties of Europe close their borders. At this time, I don't feel European'. And in a rural school near Montpellier, Amandine (F 15) burst out: 'I feel less European - we can't be proud of what has happened - what Hungary is doing now is not human.' Lola (F 15) agreed with passion: 'Europe is one - but the unity is destroyed - Hungary is not respecting the principles - Europe says we should help refugees.'

There was also intolerance on the part of some young people. In the small Belgian town of Torhout (in a very mono-ethnic area), two members of a group strongly criticized migrants. Aart (M 16) wanted to 'close the borders ... most immigrants come with a mindset that "Belgium has to change for me" - and it's not the way it goes. They don't like the culture, so they try to change Belgium'. Pim (M 16) gave an example: 'they want to build their church [mosque] on our grounds... we have a normal Christian church'. I challenged this, pointing out that Belgium had built churches in its colonies. Pim responded: 'Belgium occupied the colonies, so had the right to do what they want ... we are still above them.' Aart added: 'They are trying to change the complete Western world to their ideology.'

There was a particular perception of racial difference among some young people in the Visegrád countries, where there was stereotyping of Africans as undeveloped and primitive. Europe was sometimes characterized as 'white': in Banská Bystrica in Slovakia, Iven (M 14) said that there were no black people in Europe, and then corrected himself: 'well, there are some, immigrants'. He then sorted the continents by diet: 'American have fast food, African have what they can find, Indians have bamboos 
and plant roots, and Europeans have normal food.' Hedviga (F 13) said, 'a European ... has a white skin colour, who looks like me.' Lenka (F 16) talked of migrants: 'if you go to Paris, you'll see more migrants than Europeans ... A typical European [is] white, like me.' But there were alternative narratives: in Olsztyn (Poland), Maigozata ( $F$ 12) referred to 'racists who are against others who have a different colour of skin'.

There was much criticism of xenophobic and populist parties. Margareta in Stockholm was quoted above: she did not want to be identified with Sweden specifically because of the rising 'nationalistic movement [Sverigedemokratern], and patriotism growing stronger'.

There was fairly detailed knowledge of the racist parties, their leaders and policies in most countries in Western Europe. This was frequently described and critiqued on a country-wide basis, rather than a European one (as xenophobic parties, this is perhaps unsurprising). In the Netherlands, for example, Aalderik (M 16) disapproved of Gert Wilders and the Partij voor de Vrijheid, 'who want no one to come in. I am Dutch, but I am also a human being, and I like it more to be human than Dutch, because we are all people, humans.' In Vevey (Switzerland), Bénédicte (F 18) described the 'big problem' of the Union démocratique du centre's describing migrants as "'black sheep" - trying to get all foreigners to go away'. In the town of Roubaix (the most deprived commune in France; Maurin and Mazery, 2014), Jacques (M 18, of partly African origin) said that even if he had 'a French surname, I would be métis [mixed race]: the Front National party want to accept just French people, not others - this party is quite racist ... I am French because I was born here - but this party judge people by their origins.' Colette (F 17, of Congolese birth and descent) said that, for the Front National, 'French means the colour of the skin, not the ID card.'

There was often an acute awareness of discrimination, particularly with respect to the absence or denial of rights, and about policies both beyond and within Europe. For example, in many countries, the United States was criticized for racial discrimination, particularly by the police - this was at the time when the Black Lives Matter campaign was at its height.

Discrimination against LBGT communities in Russia was seen as a particular issue: in Slagelse (Denmark), Nelly (F 15) said that in Russia 'they don't have the right to be homosexual - they can be arrested for it, actually. It's not in the laws of all [European Union] countries yet ... It is very important that the European Union has human rights, the basic rights to be yourself.' In Zagreb, Dragan (M 14) used the acceptance of gay rights as a marker of European behaviour, even though Croatia (at the time of our discussion, about to join the European Union) 'will never be on that level of European society', because of anti-gay discrimination. Changes in attitudes were often seen generationally: in Córdoba, Agustina (F 17) said that older people 'don't understand or respect homosexual people, they see it as strange'. In Malmö, Sarah (F 16) described coming out to her mother, whose initial response was: "Well, I hope you don't marry a girl, because that won't be acceptable!" ... when she was younger ... they grew up in a whole different perspective'. But there were also some young people who were against LGBT rights. The absence of capital punishment in Europe was contrasted with the United States. In Akureyri (Iceland), Katrín (F 17) saw capital punishment as a civic rights issue: 'I don't like that about America, and that's what I like about Europe, the death sentence isn't allowed.' Social security was also often perceived as being a European value. In Hannover, Jule (F 13) contrasted Europe's compulsory medical insurance with 'the United States - there you don't have to be', and Anke (F 15) said 'unemployment benefit - in the USA they don't have this security'. In Bellaterra, Ordoño 
(M 17) referred to 'the European dream ... the most important things are social rights, to help each other'.

There was also - sometimes - acceptance of the presence of populations virtually without rights, who became, in effect, parallel societies. Such groups included both nonEuropean migrants, but particularly the Roma and Sinti populations. In many Eastern European countries there was widespread criticism by young people of the Roma. In Romania, young non-Roma said that Roma damaged the reputation of the country: in laşi, Dumitru (M 14) said that he did not feel European 'because the other countries in Europe think we are gypsies, that we do all the bad things in Europe'. Jaen argued (M 17) that the Roma themselves were responsible: 'they ... are the ones who trigger that attitude from us, because they are the ones who have misconduct.' These factors led to the ultimate othering, a denial that the local Roma were Romanian. Dumitru said that although they had Romanian passports, 'they are not really Romanians'. There were other examples of othering. In Ostrava, in the Czech Republic, one group listed the full trope of anti-ziganist characteristics (Kligman, 2001): local Roma were migrants to the city, had been rehoused in new homes, had large families for whom they claimed welfare, did not belong to the Czech Republic, were troublemakers, not 'normal', stealing, damaging civic property, doing tokenistic work, being vulgar, and had not adjusted to the majority. The courts were thought to be biased in favour of the Roma; Vavrinec (M 16) said: 'when a Roma injures a Czech person, I mean a white person, it doesn't mean anything - but when it's vice versa, it's really a bad situation.'

But there were also some more positive and sympathetic comments. In Paris, Aimée ( F 16) said: 'the biggest discrimination is against Roms people. Roms are ordinary people like us ... we are all the same.' In Sofija, Aleksandar (M 13) criticized his grandfather, who blamed the Roma for all of Bulgaria's problems. Teodor agreed: 'the Roma are not bad people-people from all groups make problems'. The exclusion of some minority populations was of widespread concern. In Haslev, Troels (M 18) spoke of the growing exclusion of 'foreign people in Denmark, and especially the Muslim[s] - which I don't like. Danish people [are] not very open-minded to people they don't know.' Luxembourg had a particularly diverse population, welcomed by most young people, but Ludovic (M 14, father from Cape Verde) observed, 'in Europe there are not so many people that are black, they treat me as though I have no value, as an African'.

Muslims were sometimes stereotyped as Islamic extremists. For example, in a discussion in the small town of Vevey, in the Swiss Romande, Julien (M 15, Swissborn of Kurdish origin, with a French forename) pointed to divisions over religion in Switzerland. Isaac denied this: 'we have Catholic, Protestant, Jews equally, and the Swiss people really respect these different religions.' Julien (not a practising Muslim) pointed to a constitutional ban on the construction of minarets, and on face veils in public areas in one canton. Isaac (M 14) responded, as Aart had in Belgium: 'if they come to Switzerland, they have to adapt to the Swiss rules - or bear the consequences.'

The potential for offending religious groups was a particular issue in 2015, after the Charlie Hebdo killings in Paris. In Faro, opinions were divided: Imaculada (F 17) thought that if 'you are offending someone's religion, it's not just a cartoon - it's a religion, with history and beliefs, not something for you to make fun of', while Andréia (F 17) said of Charlie Hebdo: 'the thing about those journals is that they criticize all of the religions - they don't take sides. And when people don't take sides, it's OK to criticize and say that your religion is stupid. And that's their opinion, OK?' There was also discussion in København of the Jyllands-Posten Muhammad cartoons controversy of 2005: Laura (F 17) said that they 'weren't typical Danish humour, they weren't really 
funny ... I don't think that was respecting the other people's culture, that was over the line'. Ulla (F 17) pointed out that Danes value freedom of speech very highly, so 'people can joke a little about each other's religion. Well, the cartoons were maybe a little out of hand.'

There was much discussion about threats to democratic freedoms, and about the potential clash between religious freedom and freedom of expression. Humanitarian values and rights were frequently mentioned as characteristics of Europe. Hans (M 18), in Dortmund, said, 'the thing that is big for Europe is that you have human rights, you can say whatever you want, that we all have this freedom ... for us it is normal that they exist - this is not standard in other countries - often we really don't think how good it is to have all these ... the right to vote, the right to free speech, press freedom, to leave the country, to say critical things, the right of the courts - these are the most important rights that we have achieved in Europe.'

In Lille, Pascaline (F 15) gave a narrative of how civic rights had spread eastwards from Western Europe after 1989: 'in France, these are values that are so deep - human rights, liberties, democracy - these are the foundations of our society. Europe shared those values - but the newer the countries, the less these values are really shared it's a good job that Europe has the power to bring these values to other countries.' There were similar sentiments, and memories of fascism, in Agustín's (M 15) remarks in Madrid: 'Spain has a confident feeling and feels very European ... we are Europeans because we share the same rights and freedoms.'

\section{Conclusion}

The 'eight specific risks' to social cohesion and values across Europe identified by Fischer's working party in 2011 (CoE, 2011), whether real or perceived threats, provide a useful checklist against which values can be identified and analysed. This article has used them to categorize and evaluate the various issues that were thrown up by groups of young people when they were asked to identify aspects of their country (and Europe) about which they were satisfied, and others that they would like to change, and were less happy about. The extent to which these issues were unforced, but generated by their own deliberations, is thus significant.

It was particularly evident that many groups were very specific about events that had taken place in the relatively recent past, or (less often) were specifically local. The contingency that this suggests does not mean that they were only responsive to live issues, to the immediate, but that they used current events to substantiate their arguments and beliefs. Moreover, the fact that the Fischer list was so frequently checked suggests that his working party had some prescience. The timescale of the fieldwork in many of the Western European states was such that it coincided with political events that led to concerns about these risks being articulated by some people, and particularly politicians, in a way that sparked opposition from many young people. For example: Finland, Sweden and Norway were the location of fieldwork in September 2014, three months after the Islamic State of the Levant (Daesh) had proclaimed itself; Austria, Italy and Switzerland were studied in late January and early February 2015, a few weeks after the Charlie Hebdo killings in Paris; the Netherlands, Belgium and parts of France in June 2015, as the refugee 'crisis' accelerated; and in more of France and Spain and Portugal in September, after the Hungarian erection of the fence; and the final fieldwork in other parts of Norway and Denmark, Germany and Luxembourg in January 2015, just after the New Year incidents in Köln. 
In the context of Fischer's list, what is important is that so many of the young people's comments can be matched to these various elements. Quotations from the various discussion groups have been given so as to give value to the ideas of the young people themselves in as direct a way as possible. Taken together, they show young people exploring together issues that they often appeared unused to discussing although many of them expressed their enjoyment in participating in these sessions. Kamilia (F 15) in Kraków said, 'if we are to learn here in school, then we should talk about this! I miss it,' and in the Czech Republic, Oldrich (M 12) said, 'we should not learn about these issues, rather we should discuss them.'

Taken together, the contributions suggest that young people are not apolitical or uninterested in current affairs, which is a common criticism of young people (Melo and Stockemer, 2014; Amnå and Ekman, 2014; Foa and Mounk, 2016). Their concerns are very much rooted in the present, and in their own particular context, but this in itself is hardly surprising, and would be equally true of many older people.

The data suggest that most young Europeans have multiple and shifting identities, which are contingent on the context of their discussion, and they are comfortable and at ease with this shifting diversity. This includes, very often, a resistance to the essentialism of nationalism and of racism. There is a concern for human rights and the denial of rights, and their focus is much more on rights being denied, rights that have been achieved in the past and that have to be fought for now. Their acceptance of multiple and shifting identities, and of what the $\operatorname{CoE}(2011: 5,34)$ report refers to as 'hyphenated Europeans', stems largely from their experience of diversity in school. In the large Danish town of Haslev, Troels (M 18) recalled when he had moved to his current school two years earlier:

I grew up in the countryside, where we didn't have any immigrants ... then I came to the Gymnasium, and suddenly there are lots of them. At the start - I had some prejudices against some of them ... they matched the way I had seen them look on the news, like the 'immigrant criminal' ... I started [by] thinking about them as what l'd seen through the media, but experiencing being with them as normal human beings ... gave a lot to me.

This does seem to support Allport's contact theory of the reduction of intergroup prejudice (Allport, 1954; Pettigrew and Tropp, 2006).

This generation of young Europeans, born since the early 1990s, appear to have distinctive characteristics in their attachment to human rights: they have, as Fulbrook (2011: 11) puts it of generation differences between Germans in the twentieth century, to be in the process of the 'construction of a collective identity on the basis of generationally defined common experiences'. Three particular sets of common experiences are significant. First, the changing demographics of Europe. Agafitei and Ivan (2016: 1) analysed Eurostat data and concluded that 'in 2014, a little more than a fifth of EU households included at least one immigrant, regardless of migration generation or migration background'. This is reflected in the participants in this study, in which at least 23 per cent were of full or partial foreign descent. This level of diversity is of very recent origin, other than in Germany, France and the UK; in most other European countries, parents would have been much less likely to encounter diversity in their schooling, and grandparents highly unlikely. The second change for this generation has been in the political context, with the end of the Cold War, which has particularly affected generational perspectives in the states that have joined the EU since 2004. And the third change has been the rise of social media, and particularly its use by young people. 
The significance of this study may lie particularly in the methodology: the opportunity to talk in small groups, in a neutral situation, with a leader who very rarely asks leading questions, who does not always stay neutral, but allows a range of voices, and who listens and responds to their points. Deliberation nearly always seemed to progress over the hour or so, and the young people appeared to enjoy it, and to participate and listen. By giving credence and value to their ideas, and letting them use and advance their own vocabulary, not reacting to adult-prompted terms and categorizations, deliberative discussions can allow and encourage young people to develop their ideas from the instrumental to the idealistic. The comments made in nearly all the groups suggest that this was rarely done in their experience.

Could deliberative discussions be promoted in schools? The process is timeconsuming, involving small groups, and would probably require some significant training. More particularly, it would be seen as controversial by some schools and teachers, and particularly by parents and policymakers.

\section{Acknowledgements}

I am grateful to the European Commission for supporting my travel expenses for the first part of this research (as part of my Jean Monnet chair), and to London Metropolitan University for a contribution towards some of the travel expenses of the second part. I am particularly grateful to the 210 colleagues - friends - who facilitated my meetings with the young people.

\section{Notes on the contributor}

Alistair Ross is Emeritus Professor at London Metropolitan University and holds an ad personam Jean Monnet chair from the European Commission. He directed the Institute of Policy Studies in Education (2000-9) and the European Commission Socrates Academic Network Children's Identities and Citizenship in Europe (19982008). A Fellow of the Academy of Social Sciences, his books include Curriculum Construction and Critique (Routledge, 2000), A European Education (Trentham, 2008), Understanding the Construction of Identities by Young New Europeans (Routledge, 2016) and Finding Political Identities (Palgrave, 2019).

\section{References}

Agafiței, M. and Ivan, G. (2016) 'First and second-generation immigrants - statistics on main characteristics'. Online. https://tinyurl.com/yxy8n4gy (accessed 14 November 2019).

Allport, G.W. (1954) The Nature of Prejudice. Reading, MA: Addison-Wesley.

Amnå, E. and Ekman, J. (2014) 'Standby citizens: Diverse faces of political passivity'. European Political Science Review, 6 (2), 261-81.

Anderson, B. (1992) Imagined Communities: Reflections on the origin and spread of nationalism, 2nd ed. London: Verso.

Anthias, F. (2012) 'Transnational mobilities, migration research and intersectionality: Towards a translocational frame'. Nordic Journal of Migration Research, 2 (2), 102-10.

Arnett, J.J. (2008) 'The neglected 95\%: Why American psychology needs to become less American'. American Psychologist, 63 (7), 602-14.

Balescu, O. (2009) 'Reflections on European identity: The case of Eastern European countries'. In Dolejšiová, D. and García López, M.Á. (eds) European Citizenship - In the Process of Construction... Challenges for citizenship, citizenship education and democratic practice in Europe. Strasbourg: Council of Europe Publishing, 44-54.

Bauman, Z. (2000) Liquid Modernity. Cambridge: Polity Press. 
BERA (British Educational Research Association) (2004) Revised Ethical Guidelines for Educational Research. Southwell: British Educational Research Association.

BERA (British Educational Research Association) (2011) Ethical Guidelines for Educational Research. Rev. ed. London: British Educational Research Association.

Bohnsack, R. (2000) Rekonstruktive Sozialforschung: Einführung in die Methodologie und Praxis qualitativer Forschung. 4th ed. Opladen: Leske und Budrich.

Bourdieu, P. (1973) 'L'opinion publique n'existe pas'. Les temps modernes, 318, 1292-309.

Bruter, M. (2005) Citizens of Europe? The emergence of a mass European identity. Basingstoke: Palgrave Macmillan.

CEC (Commission of the European Communities) (1992) 'Treaty on European Union, signed at Maastricht on 7 February 1992'. Official Journal of the European Communities, C 191, Vol. 35, 29 July. Online. https://tinyurl.com/tkenym9 (accessed 14 November 2019).

CoE (Council of Europe) (2011) Living Together: Combining diversity and freedom in 21st-century Europe: Report of the Group of Eminent Persons of the Council of Europe. Strasbourg: Council of Europe Publishing.

Foa, R.S. and Mounk, Y. (2016) 'The danger of deconsolidation: The democratic disconnect'. Journal of Democracy, 27 (3), 5-17.

Fulbrook, M. (2011) Dissonant Lives: Generations and violence through the German dictatorships. Oxford: Oxford University Press.

Gellner, E. (1983) Nations and Nationalism. Oxford: Blackwell.

Gugglberger, L., Adamowitsch, M., Teutsch, F., Felder-Puig, R. and Dür, W. (2015) 'The use of group discussions: A case study of learning about organisational characteristics of schools'. International Journal of Social Research Methodology, 18 (2), 127-43.

Henrich, J., Heine, S.J. and Norenzayan, A. (2010) 'The weirdest people in the world?'. Behavioral and Brain Sciences, 33 (2-3), 61-83.

Kligman, G. (2001) 'On the social construction of "otherness": Identifying "the Roma" in postsocialist communities'. Review of Sociology, 7 (2), 61-78.

Loos, P. and Schäffer, B. (2001) Das Gruppendiskussionsverfahren: Theoretische Grundlagen und empirische Anwendung. Opladen: Leske und Budrich.

Lutz, W., Kritzinger, S. and Skirbekk, V. (2006) 'The demography of growing European identity'. Science, 314 (5798), 425.

Maurin, L. and Mazery, V. (2014) 'Les taux de pauvreté des 100 plus grandes communes de France'. Compas études, 11, 1-4.

Melo, D.F. and Stockemer, D. (2014) 'Age and political participation in Germany, France and the UK: A comparative analysis'. Comparative European Politics, 12 (1), 33-53.

Pettigrew, T.F. and Tropp, L.R. (2006) 'A meta-analytic test of intergroup contact theory'. Journal of Personality and Social Psychology, 90 (5), 751-83.

Pop, V. (2016) 'EU launches review of Polish Government's court changes'. Wall Street Journal, 13 January. Online. https://tinyurl.com/yx6cf7ol (accessed 14 November 2019).

Rochat, P. (2010) 'What is really wrong with a priori claims of universality? Sampling, validity, process level, and the irresistible drive to reduce'. Behavioral and Brain Sciences, 33 (2-3), 107-8.

Ross, A. (2015) Understanding the Constructions of Identities by Young New Europeans: Kaleidoscopic selves. London: Routledge.

Ross, A. (2019) Finding Political Identities: Young people in a changing Europe. Cham: Palgrave Macmillan.

Rozin, P. (2001) 'Social psychology and science: Some lessons from Solomon Asch'. Personality and Social Psychology Review, 5 (1), 2-14.

Scheunpflug, A., Krogull, S. and Franz, J. (2016) 'Understanding learning in world society: Qualitative reconstructive research in global learning and learning for sustainability'. International Journal of Development Education and Global Learning, 7 (3), 6-23.

Shachar, A. (2009) The Birthright Lottery: Citizenship and global inequality. Cambridge, MA: Harvard University Press.

Wagener, M. (2018) 'What do young people learn when sponsoring a child in the Global South? Empirical findings from Germany'. International Journal of Development Education and Global Learning, 10 (1), 90-102. 